\title{
The effect of rootstock on apple tree bearing stability in a cooler climate
}

\author{
Darius Kviklys, Alina Čeidaitè, Juozas Lanauskas, Nobertas Uselis, Giedrè Samuolienè \\ Institute of Horticulture, Lithuanian Research Centre for Agriculture and Forestry, \\ Kauno 30, LT54333 Babtai, Kaunas, Lithuania \\ e-mail: dkviklys@gmail.com
}

\begin{abstract}
The effect of rootstock on apple yield, productivity and alternate bearing was investigated at the Institute of Horticulture, Lithuanian Research Centre for Agriculture and Forestry during a six-year period in a full bearing orchard. Apple cultivars 'Ligol' and 'Auksis' grafted on M.26 semi-dwarf rootstock; M.9, B.396, P 66, P 67 and Pure 1 dwarf rootstocks; and P 59, P 22, P 61, P 62 and PB.4 super-dwarf rootstocks were tested. Rootstock had a significant effect on apple tree growth, average yield and cumulative yield efficiency. Alternate apple bearing did not depend on rootstock vigour. Constant correlations between bearing regularity, average yield and cumulative yield efficiency were not established and differed on a cultivar or rootstock level. On the average of both tested cultivars, a more regular apple yield was recorded on Pure 1, P 59 and B.396 rootstocks. A significantly higher alternate bearing index was established on P 67, P 62 and M.9 rootstocks.
\end{abstract}

Key words: biennial bearing, crop load, Malus domestica Borkh., trunk circumference, yield efficiency

\section{Introduction}

In north eastern European countries frost is one of the limiting factors for rootstocks. Damages are recorded in trials and in commercial orchards, therefore more hardy rootstocks are needed (Wertheim 1998). Rootstocks originating from breeding programmes in Poland, Russia, Latvia or Belarus are supposed to be more adapted to extreme winter conditions with low temperatures. Numerous trials have revealed differences between rootstocks in tree vigour control, precocity and fruit quality (Barritt et al. 1997, Czynczyk et al. 2009, Kviklys et al. 2013). However, fewer results are given for the effect of rootstock on apple bearing stability (Jonkers 1979). Investigation of alternate bearing index $(A B I)$ in other crops indicate the effect of rootstock on $A B I$ in oranges (El-Zeftawi and Thornton 1975) and pears (Bertelsen and Callesen 2001).

Alternate bearing is characterized by a large yield in one year and low yield in the next year. Alternate bearing is widespread throughout cultivated fruit trees and shrubs, both deciduous and evergreen trees and temperate, subtropical and tropical fruits (Monselise and Goldschmidt 1982).

Different theories explain the phenomenon: lack of nutrients for initiation of fruit buds, production of inhibiting hormones in seeds (Jackson 2003), competition between seeds and developing buds for the compounds that promote flowering (Dennis and Neilsen 1999) and strong genetics of certain apple cultivars (Guitton et al. 2012). Cultivar selection is one precondition for preventing alternate bearing (Atay et al. 2013). Widely grown apple cvs. 'Gala' and 'Idared' usually produce an annual yield, 'McIntosh' has a moderate and 'Golden Delicious' a high ABI (Schupp 2011).

Factors such as light, temperature and the availability of photosynthates have an effect on tree bearing stability (Wunsche and Ferguson 2005). Orchard site, orchard management, fertilization and a pruning programme giving optimal vegetative growth can also have an influence on annual production. Crop load management by pruning and hand and chemical thinning is a common practice to prevent alternate bearing (Schmidt et al. 2009, Pellerin et al. 2011).

Apple rootstocks regulate tree growth, precocity, water and nutrient uptake and transport, and change the biochemical content of the fruit (Koepke and Dhingra 2013, Kviklys et al. 2014, Samuolienè et al. 2016), all of which can have an impact on bearing regularity. The aim of this study was to investigate the impact of rootstock on apple tree bearing peculiarities. 


\section{Materials and methods}

The experiment was performed at the Institute of Horticulture, Lithuanian Research Centre for Agriculture and Forestry during $2009-2014\left(55^{\circ} 60^{\prime} \mathrm{N}, 23^{\circ} 48^{\prime} \mathrm{E}\right)$. The chemical characteristics of the soil were: clay loam, $\mathrm{pH}-$ 7.3 , humus $-2.8 \%, \mathrm{P}_{2} \mathrm{O}_{5}-255 \mathrm{mg} \mathrm{kg}^{-1}, \mathrm{~K}_{2} \mathrm{O}-230 \mathrm{mg} \mathrm{kg}^{-1}$. Annual average precipitation is $630 \mathrm{~mm}$, average temperature is $6.5-7^{\circ} \mathrm{C}$. There was no severe spring frost damage or other weather extremes during the trial period.

The experimental design was a randomized complete block design with ten replications and one single tree in each plot. The cultivars' Auksis' and 'Ligol' on M.26 (semi-dwarf rootstock); M.9, B.9, B.396, P 66, P 67 and Pure 1 (dwarf rootstocks); and P 59, P 22, P 61, P 62 and PB.4 (super-dwarf rootstocks). The trees were spaced at $4 \times 1.5 \mathrm{~m}$ and planted in spring 2005. Trees were trained as slender spindles.

The trial started when the trees were four years old and lasted a six-year period in the orchard at full bearing stage. Fruit thinning was not performed, in order to maintain the apparent effect of the rootstock.

Tree growth was evaluated by measuring the trunk diameter $30 \mathrm{~cm}$ above soil surface, and converting to trunk cross sectional area (TCSA) in $\mathrm{cm}^{2}$. Fruit yield was measured in $\mathrm{kg}_{\text {tree-1 }}$. Cumulative yield efficiency $\left(\mathrm{kg} \mathrm{cm}^{-2}\right.$ of TCSA) was calculated as the ratio of cumulative six-year yield and the final TCSA in 2014. Average fruit weight was measured in $g$ on the whole tree basis. 50 fruits from every tree were graded according to the diameter to following size classes $<60 \mathrm{~mm}, 65-70 \mathrm{~mm}, 70-75 \mathrm{~mm}, 75-80 \mathrm{~mm}$ and $>85 \mathrm{~mm}$.

ABI was calculated according to Monselise and Goldschmidt (1982):

$A B I=($ year 1 yield $)-($ year 2 yield $) /($ year 1 yield + year 2 yield $)$,

where $A B I=0$ is no alternate bearing and $A B I=1.0$ is complete alternate bearing.

The average $A B I$ was calculated for the whole period of investigations according to the formula:

$A B I=\left(A B I_{(2009-10)}+A B I_{(2010-11)}+A B I_{(2011-12)}+A B I_{(2012-13)}+A B I_{(2013-14)}\right) / 5$

The data was evaluated by general analysis of variance (ANOVA) for randomized block designs using the statistical program SAS (SAS Institute, Cary, N.C.) testing for differences between the cultivars and rootstock on yields. Unless noted otherwise, only results significant at $p<0.05$ are discussed.

\section{Results and discussion}

Fruit thinning is claimed to be the best practice to avoid irregular bearing in apples. Different chemical and non-chemical thinning agents, time of application and weather influence on thinning efficiency have been widely tested (Lakso et al. 2006, Kviklys and Robinson 2010). Unfortunately, a constant effect on crop stability has not yet been achieved, pointing at the necessity of evaluating other factors; one of these could be the rootstock (Koepke and Dhingra 2013). Despite a different fruit yield depending on a particular rootstock, bearing stability was similar (Fig. 1). After a year with a high crop, a low cropping year followed. Apple yield recovered again in the third year. A more stable average yield counted on a ten tree basis was recorded for cv. 'Ligol' on P 59 rootstock, but trees on this rootstock had an extremely poor yield. Rootstocks P 62 and M.26 also determined a more consistent yield on average, but at the single tree level alternate bearing was highly expressed with some trees on the same rootstock having plenty of fruit and others none.

The yield of cv. 'Auksis' on M.9, which was one of the best rootstocks for it, varied from $2 \mathrm{~kg} \mathrm{tree}^{-1}$ in 2010 to 41.7 $\mathrm{kg} \mathrm{tree}^{-1}$ in 2013, or from 3.4 to $69.5 \mathrm{t} \mathrm{ha}^{-1}$, respectively. The yield of cv. 'Ligol' on B.396 rootstock varied from 9.3 $\mathrm{kg}$ tree $^{-1}$ in 2010 to $47 \mathrm{~kg}$ tree $\mathrm{e}^{-1}$ in 2013 , or 15.5 to $78.3 \mathrm{t} \mathrm{ha}^{-1}$, respectively. 

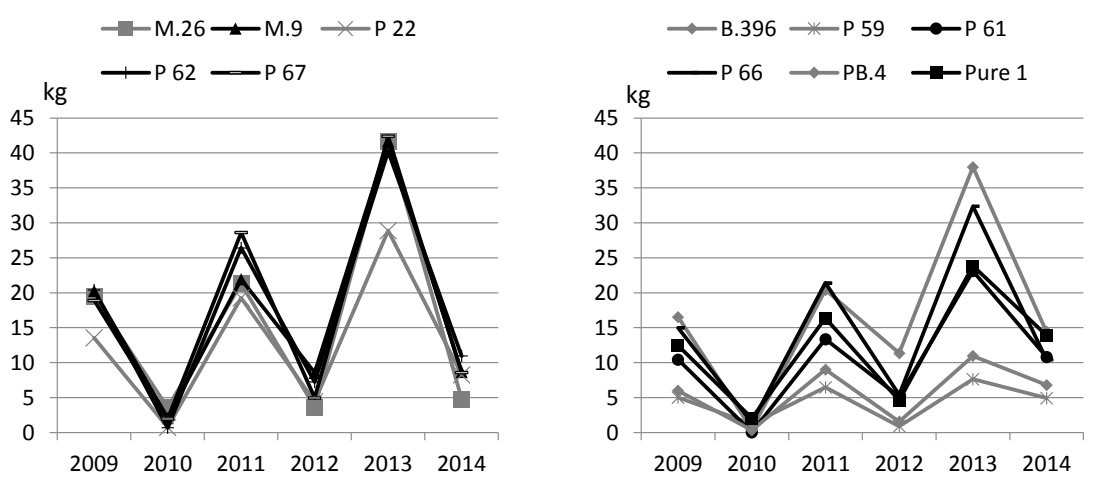

cv. 'Ligol'
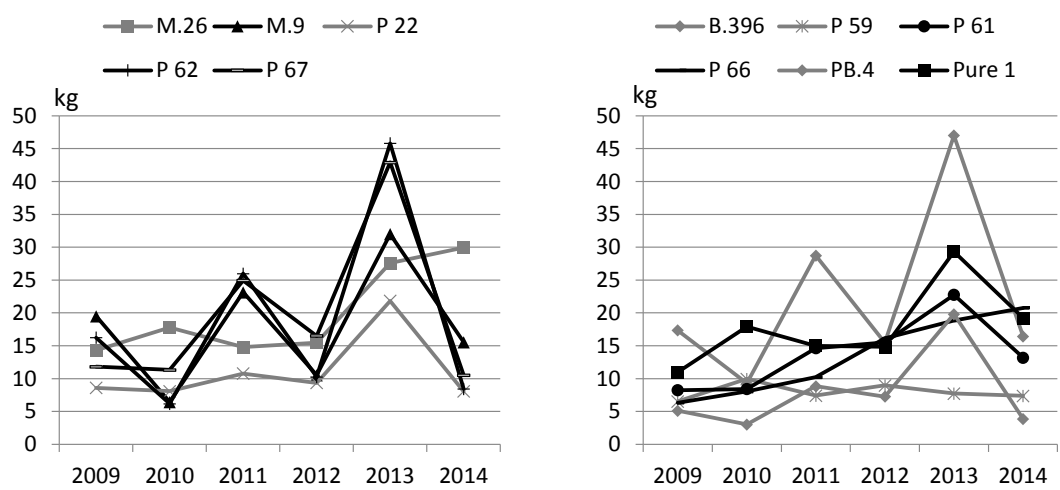

Fig. 1. Rootstock effect on apple yield (kg tree $\left.{ }^{-1}\right)$ of cv. 'Auksis' (two upper pictures) and cv. 'Ligol' (two lower pictures)

Cv. 'Ligol' is known as an alternate bearing cultivar (Czynzyk et al. 2009), while cv. 'Auksis' is claimed to be less prone to biennial bearing (Kviklys et al. 2012). Despite that, irregular bearing was highly expressed for both tested cultivars. The ABI averaged 0.72 for cv. 'Auksis' and 0.70 for cv. 'Ligol' (Table 1). The ABI of cv. 'Auksis', depending on rootstock, varied from 0.62 on P 59 rootstock up to 0.78 on P 67 and P 62 ; the ABI of cv. 'Ligol' varied from 0.58 on B.396 rootstock up to $0.80-0.81$ on M.9 and P 67 . On the average of both tested cultivars, a more regular apple yield was recorded on Pure 1, P 59 and B.396 rootstocks. Significant differences between these rootstocks and P 67, P 62 and M.9 were detected. Even though there were significant differences between rootstocks, such high $A B I$ values indicate that all trees were prone to biennial bearing independent of the rootstock on which they were grafted.

Table 1. Rootstock effect on alternate bearing index, average of 2009-2014

\begin{tabular}{cccc}
\hline Rootstock & cv. 'Auksis' & cv. 'Ligol' & Average \\
\hline B.396 & $0.70 \mathrm{abc}$ & $0.58 \mathrm{~d}$ & $0.64 \mathrm{c}$ \\
M.26 & $0.76 \mathrm{a}$ & $0.69 \mathrm{bc}$ & $0.72 \mathrm{ab}$ \\
M.9 & $0.73 \mathrm{ab}$ & $0.81 \mathrm{a}$ & $0.77 \mathrm{a}$ \\
P 22 & $0.76 \mathrm{a}$ & $0.69 \mathrm{bc}$ & $0.73 \mathrm{ab}$ \\
P 59 & $0.62 \mathrm{c}$ & $0.64 \mathrm{~cd}$ & $0.63 \mathrm{c}$ \\
P61 & $0.71 \mathrm{abc}$ & $0.65 \mathrm{~cd}$ & $0.68 \mathrm{bc}$ \\
P 62 & $0.78 \mathrm{a}$ & $0.79 \mathrm{ab}$ & $0.78 \mathrm{a}$ \\
P 66 & $0.72 \mathrm{abc}$ & $0.67 \mathrm{bcd}$ & $0.69 \mathrm{bc}$ \\
P 67 & $0.78 \mathrm{a}$ & $0.80 \mathrm{a}$ & $0.79 \mathrm{a}$ \\
PB.4 & $0.74 \mathrm{a}$ & $0.78 \mathrm{ab}$ & $0.76 \mathrm{ab}$ \\
Pure 1 & $0.64 \mathrm{bc}$ & $0.59 \mathrm{~cd}$ & $0.62 \mathrm{c}$ \\
Average & 0.72 & 0.70 & 0.71 \\
\hline
\end{tabular}


Comparing both cultivars on the same rootstocks, cultivar-rootstock interaction was found only with B.396 rootstock, where cv. 'Ligol' grown on it had a significantly lower ABI than cv. 'Auksis'.

Rootstock had a significant effect on average apple yield. Significantly, the highest average yield of cv. 'Auksis' was obtained on dwarf rootstocks B.396, M.9, P 67 and P 62 (Fig. 2). Cv. 'Ligol' had the highest yield on B.396 (Fig. 3). The lowest harvest of both tested cultivars was recorded on super-dwarf rootstocks PB.4 and P 59. Some different effects of rootstock on apple yield were noticed in the young orchard (Kviklys et al. 2013) where cv. 'Ligol' had an equal yield on rootstocks B.396 and M.9. On the average of both cultivars and all rootstocks, ABI did not correlate with the average yield. The lowest ABI for cv. 'Auksis' was on P 59 which also had the lowest yield. At the same time, the lowest ABI for cv. 'Ligol' was on B.396 which gave significantly the highest average yield. In some cases, the ABI was opposite for rootstocks with similar average yield: Pure 1 and P 22 for cv. 'Auksis', and M.9 and Pure 1 for cv. 'Ligol'.

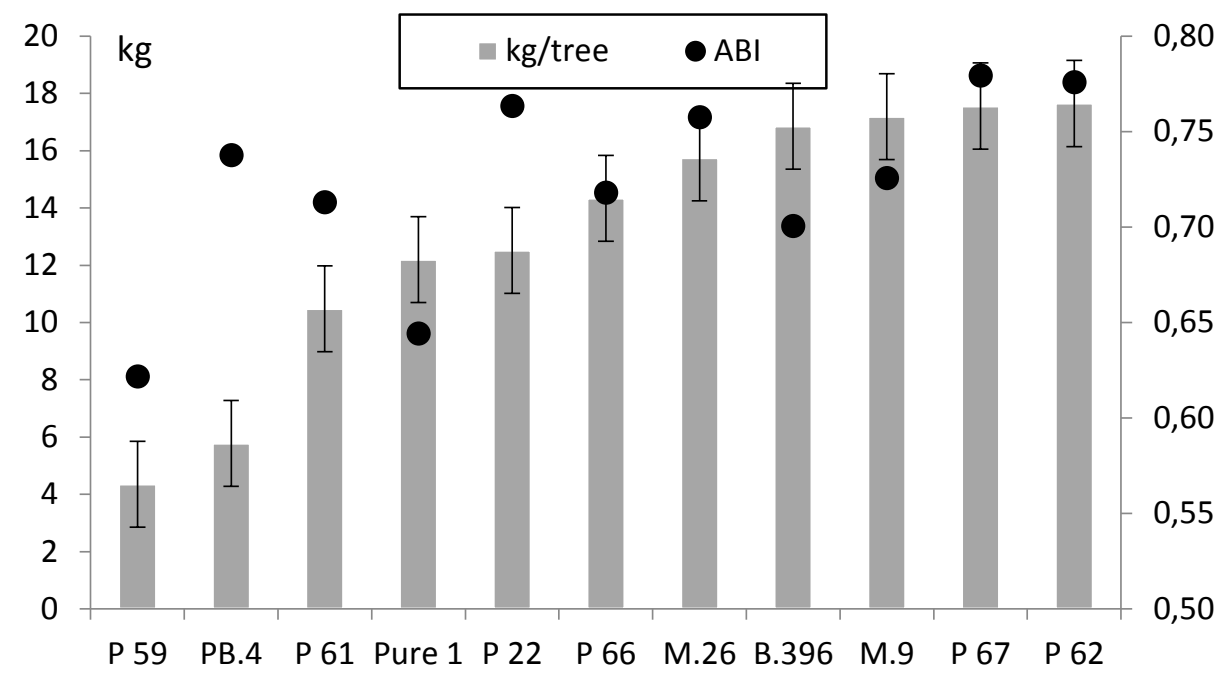

Fig. 2. Rootstock effect on average yield ( $\mathrm{kg}$ tre $^{-1}$ ) of cv. 'Auksis' and $A B I$ (alternate bearing index) (rootstocks sorted in yield increasing order), 2009-2014. Error bars on the columns indicate least significant difference (LSD) at $p<0.05$.

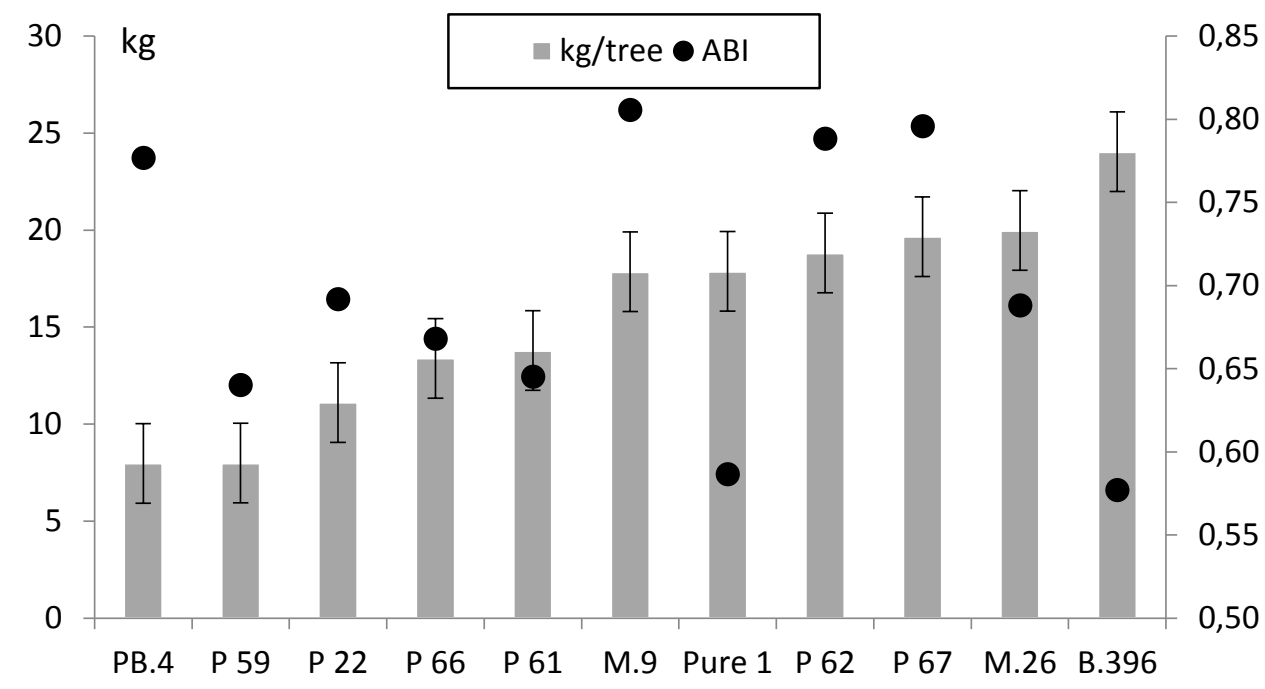

Fig. 3. Rootstock effect on average yield ( $\mathrm{kg} \mathrm{tree}^{-1}$ ) of cv. 'Ligol' and ABI (alternate bearing index) (rootstocks sorted in yield increasing order), 2009-2014. Error bars on the columns indicate least significant difference (LSD) at $p<0.05$. 
When rootstocks were examined separately, significant correlation between $A B I$ and average yield was established only for cv. 'Auksis' on P 62, M.26 and PB.4 rootstocks - the higher the average yield, the less alternate bearing (Table 2).

Rootstock had a significant effect on average fruit weight. Significantly, the smallest fruits of cv. 'Auksis' were obtained on PB.4, P 59, and Pure 1 (Fig. 4). Cv. 'Ligol' had the smallest fruits on P 59 (Fig. 5). On the average of both cultivars the biggest fruits were obtained on P 62, significantly smaller on super-dwarfing rootstocks P 59 and Pure 1. Fruit weight in particular season depended on the yield - the higher the yield the smaller the fruits.

Despite of significant rootstock effect on the average fruit weight no correlation was found between $A B I$ and fruit weight (the data is not presented).

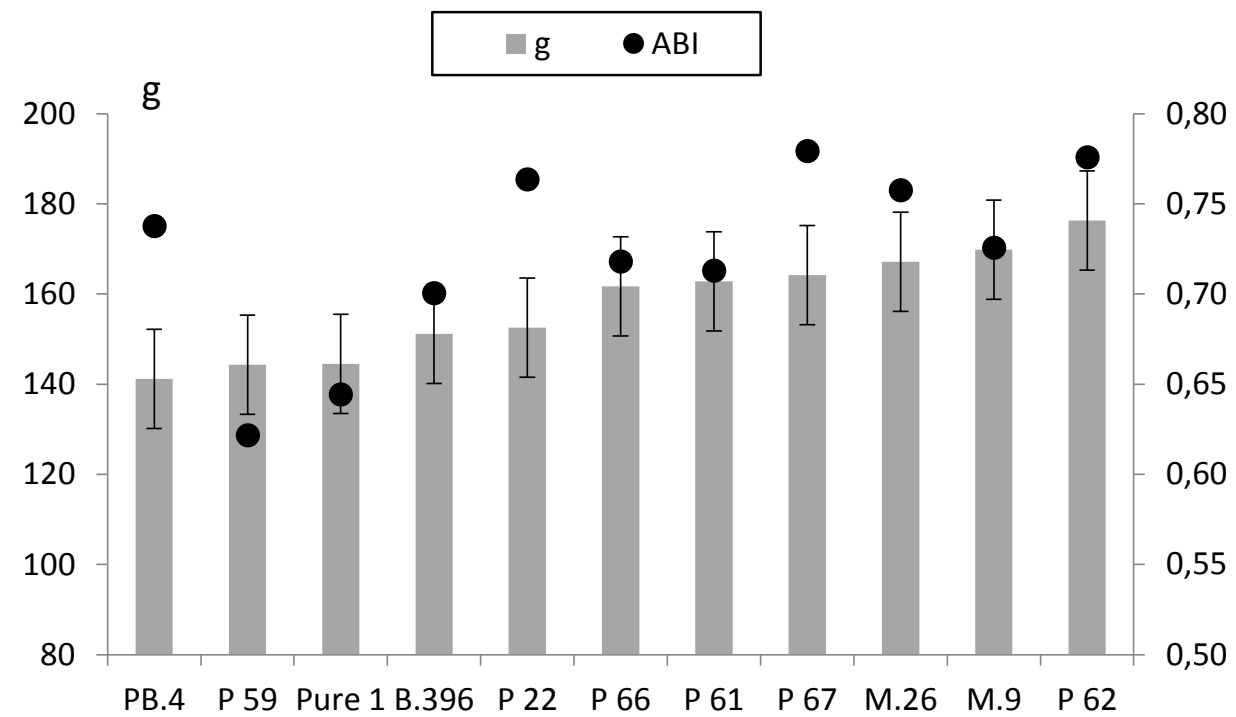

Fig. 4. Rootstock effect on average fruit weight (g) of cv. 'Auksis' and ABI (alternate bearing index) (rootstocks sorted in fruit weight increasing order), 2009-2014. Error bars on the columns indicate least significant difference (LSD) at $p<0.05$.

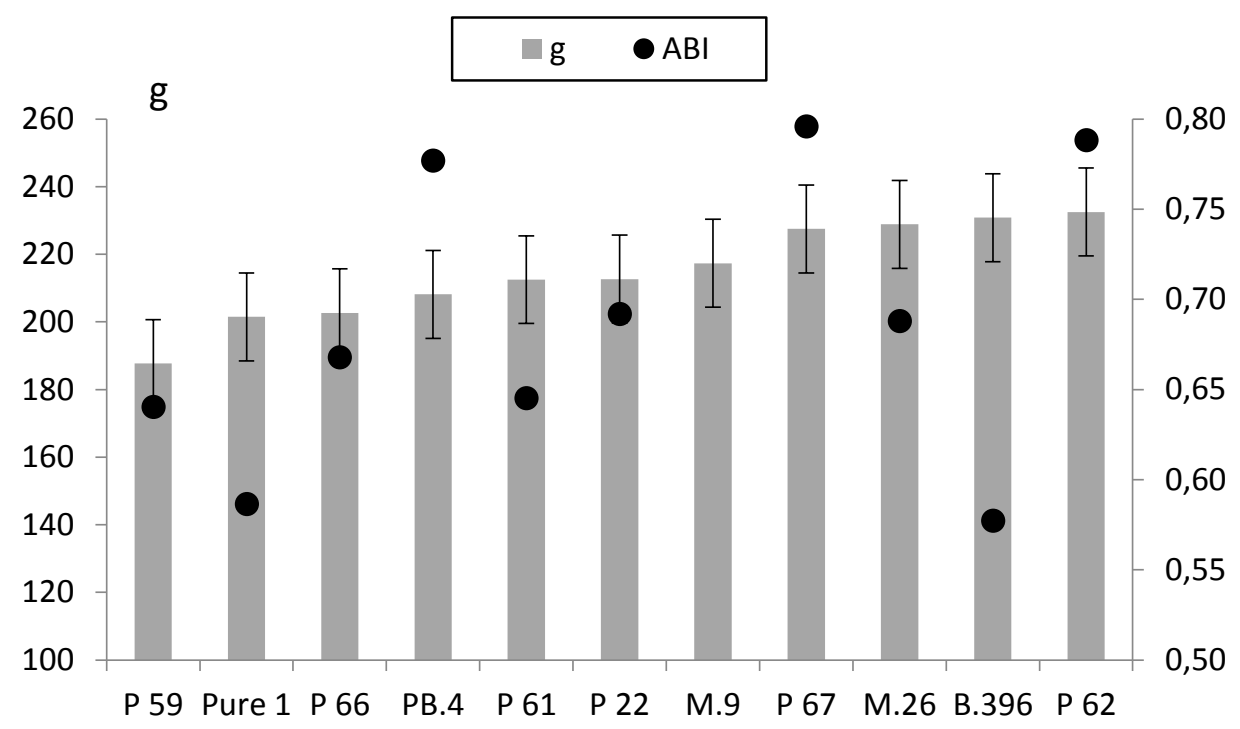

Fig. 5. Rootstock effect on average fruit weight (g) of cv. 'Ligol' and ABI (alternate bearing index) (rootstocks sorted in fruit weight increasing order), 2009-2014. Error bars on the columns indicate least significant difference (LSD) at $p<0.05$. 
On the average of both cultivars according to tree growth control, apple rootstocks are divided into the following groups: super-dwarfing - PB.4, P 61, P 59, P 22 and Pure 1, dwarfing - M.9, B.396, P 62, P 66 and P 67, and semi-dwarfing - M.26. The same rootstock order was already established in the young orchard (Kviklys et al. 2013). Rootstock had a significant effect on tree vigour (Figs. 6 and 7); however, the ABI did not correlate with rootstock vigour class. For example, a high $\mathrm{ABI}$ was recorded for separate rootstocks belonging to different groups such as super-dwarfing PB 4, dwarfing P 67 and semi-dwarfing M.26 for cv. 'Auksis'. Barrit et al. (1997) found that the incidence of biennial bearing with cvs. 'Golden Delicious' and 'Granny Smith', increased as rootstock vigour increased, but with 'Redchief Delicious' biennial bearing declined as rootstock vigour increased. Racsko and Miller (2011) confirmed the same ranking of rootstocks in alternate bearing as the ranking for their vigour. Possibly, it was established because of more contrasting in vigour rootstocks (dwarfing M.9, semi-vigorous MM.106 and vigorous seedling rootstock) were tested.

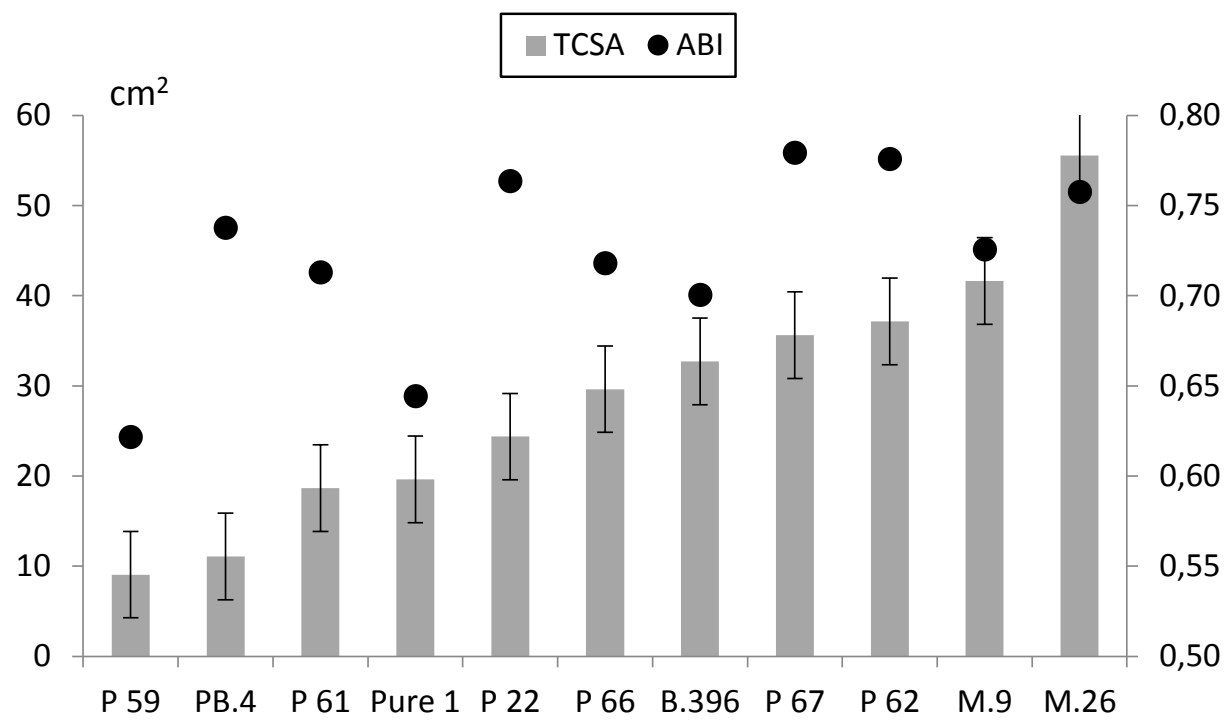

Fig. 6. Rootstock effect on tree vigour TCSA (trunk cross sectional area, $\mathrm{cm}^{2}$ ) of cv. 'Auksis' and $\mathrm{ABI}$ (alternate bearing index) (rootstocks sorted in tree vigour increasing order), 2009-2014. Error bars on the columns indicate least significant difference (LSD) at $p<0.05$.

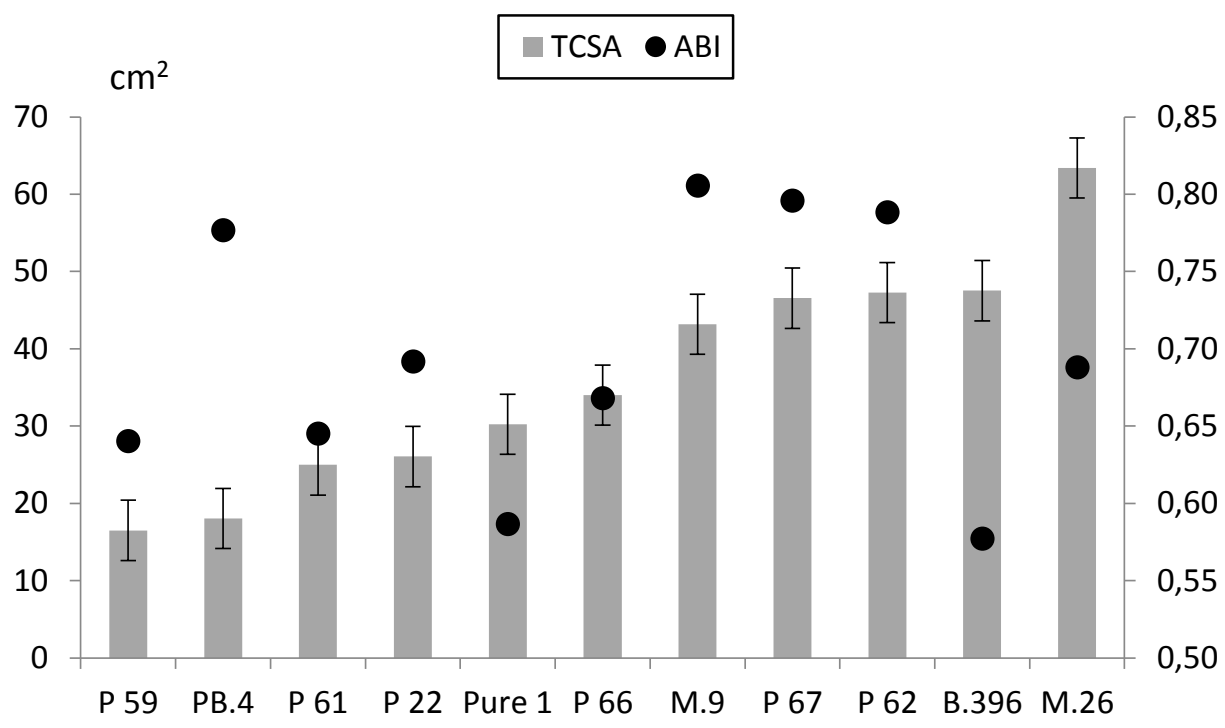

Fig. 7. Rootstock effect on tree vigour TCSA (trunk cross sectional area, $\mathrm{cm}^{2}$ ) of cv. Ligol and $\mathrm{ABI}$ (alternate bearing index) (rootstocks sorted in tree vigour increasing order), 2009-2014. Error bars on the columns indicate least significant difference (LSD) at $p<0.05$. 
Analysing cultivars and rootstocks separately, correlation between $A B I$ and tree vigour was established for both cultivars on P 67 rootstock. The stronger the tree growth, the higher the alternate bearing which occurred, $r$ (correlation coefficient) was for cv. 'Auksis' 0.49 and for cv. 'Ligol' 0.52) (Table 2). On the other hand, the stronger the tree growth of cv. 'Auksis' on B.396 and PB.4 rootstocks, the more regular the yield recorded $(r=-0.51$ and -0.44 , respectively).

On average, tree efficiency is adversely related to tree growth. Rootstocks that induce lower tree growth determine higher yield efficiency, as has been reported in numerous trials (Hirst et al. 2001, Piestrzeniewicz et al. 2009). Apple trees on the super-dwarfing P 22 and P 61 rootstocks had significantly higher cumulative yield efficiency. Additionally, cv. 'Ligol' was very efficient on Pure 1 rootstock, while cv. 'Auksis' was efficient on P 67 rootstock. Confirming our results, rootstock P 67 was also found to be one of the most efficient in several trials performed in Poland (Zurawicz et al. 2011). Both cultivars on semi-dwarfing M.26 exhibited the lowest cumulative yield efficiency. Nevertheless, on the average of both cultivars and all rootstocks, ABI did not correlate with tree cumulative yield efficiency. Investigating rootstocks separately, a tendency to more regular yield on more efficient trees was established (Table 2). On the other hand, high ABI correlation with tree efficiency was found only for some rootstocks - P 67 for cv. 'Auksis' ( $r=-0.86)$, and P 59 and P 61 for cv. 'Ligol' ( $r=-0.73$ and -0.71 , respectively).

Dwarfing M.9 rootstock is known for its high yield efficiency and more regular flowering (Wertheim 1998). High efficiency of M.9 rootstock was confirmed by our results, too; however, the average ABI with cv. 'Auksis' and highest ABI with cv. 'Ligol' did not reveal advantages of M.9 as a rootstock for decreasing alternate bearing of apples.

Table 2. Correlation coefficients ( $r$ ) between alternate bearing index ABI and tree vigour TCSA (trunk cross sectional area ), cumulative yield efficiency and average yield

\begin{tabular}{|c|c|c|c|c|c|c|}
\hline \multirow[b]{2}{*}{ Rootstock } & \multicolumn{2}{|c|}{ TCSA } & \multicolumn{2}{|c|}{ Cumulative yield efficiency } & \multicolumn{2}{|c|}{ Average yield } \\
\hline & cv. 'Auksis' & cv. 'Ligol' & cv. 'Auksis' & cv. 'Ligol' & cv. 'Auksis' & cv. 'Ligol' \\
\hline B.396 & -0.51 & -0.09 & 0.26 & -0.03 & -0.1 & -0.37 \\
\hline M.26 & -0.14 & 0.57 & 0.06 & -0.24 & $-0.63^{*}$ & -0.26 \\
\hline M.9 & 0.16 & -0.09 & -0.40 & 0.32 & 0.28 & 0.15 \\
\hline P 22 & 0.08 & $0.68 *$ & -0.06 & $-0.63 *$ & -0.27 & 0.29 \\
\hline P 59 & 0.25 & -0.43 & -0.19 & $-0.73 *$ & -0.07 & -0.57 \\
\hline P 61 & 0.38 & 0.43 & -0.31 & $-0.71 *$ & 0.09 & -0.29 \\
\hline P 62 & -0.16 & -0.43 & -0.40 & -0.22 & $-0.75^{*}$ & -0.46 \\
\hline P 66 & 0.03 & -0.20 & -0.36 & -0.25 & -0.13 & -0.43 \\
\hline P 67 & 0.49 & 0.52 & $-0.86 * *$ & -0.04 & 0.22 & 0.34 \\
\hline PB.4 & -0.44 & -0.29 & -0.05 & -0.29 & $-0.63 *$ & -0.42 \\
\hline Pure 1 & $0.65^{*}$ & 0.38 & $-0.63^{*}$ & -0.30 & -0.39 & -0.27 \\
\hline
\end{tabular}

\section{Conclusions}

According to tree growth control tested rootstocks are divided into the following groups: super-dwarfing - PB.4, P 61, P 59, P 22 and Pure 1, dwarfing - M.9, B.396, P 62, P 66 and P 67, and semi-dwarfing - M.26.

The highest average yield of cv. 'Auksis' was obtained on dwarfing B.396, M.9, P 67 and P 62 rootstocks. Cv. 'Ligol' trees gave the highest average yield on B.396. The lowest average yield of both cultivars was on super-dwarfing rootstocks P 59 and BP.4. On the average of both cultivars the biggest fruits were obtained on P 62, significantly smaller on super-dwarfing rootstocks P 59 and Pure 1.

On average, alternate apple bearing was not affected by rootstock vigour class, apple yield, average fruit weight and cumulative yield efficiency. Analysing rootstocks separately, a high correlation between $\mathrm{ABI}$ and cumulative yield efficiency was found for cv. 'Auksis' on dwarfing P 67, and for cv. 'Ligol' on super-dwarfing P 59 and P 61 rootstocks. High correlation between ABI and average yield was established for cv. 'Auksis' on dwarfing P 62, semi-dwarfing M.26 and super-dwarfing PB.4 rootstocks.

Despite significant differences between rootstocks in growth control, average yield, average fruit weight and yield efficiency, a more regular apple yield was recorded on super-dwarfing Pure 1, P 59 and dwarfing B.396 rootstocks. 


\section{Acknowledgements}

This work was supported by a grant from the Research Council of Lithuania, project No. MIP-036/2014.

\section{References}

Atay, A.N., Koyuncu F. \& Atay E. 2013. Relative susceptibility of selected apple cultivars to alternate bearing. Journal of Biological \& Environmental Sciences 7: 81-86.

Barritt, B.H., Konishi, B.S. \& Dilley, M.A. 1997. Tree size, yield and biennial bearing relationships with 40 apple rootstocks and three scion cultivars. Acta Horticulturae 451: 105-112.

Bertelsen, M.G. \& Callesen, O. 2001. Performance of 'Clara frijs' pear on seven rootstocks. Acta Horticulturae 557: 145-151.

Czynczyk, A., Bielicki, P. \& Bartosiewicz, B. 2009. Results of growing three apple cultivars grafted on a number of polish and english rootstocks and their subclones. Journal of Fruit and Ornamental Plant Research 17: 73-83.

Dennis, F.G. \& Neilsen, J.C. 1999. Physiological factors affecting biennial bearing in tree fruit: the role of seeds in apple. HortTechnology 9: 317-322.

El-Zeftawi, B.M. \& Thornton, L.R. 1975. Effects of rootstocks and fruit stripping on alternate bearing of Valencia orange trees. Journal of Horticultural Science 50: 219-226.

Guitton, B., Kelner, J.J., Velasco, R., Gardiner, S.E., Change, D. \& Costes, E. 2012. Genetic control of biennial bearing in apple. Journal of Experimental Botany 63: 131-149.

Hirst, P.M., Autio, W.R., Barden, J.A., Brown, G.R., Crassweller, R.M., Domoto, P.A. \& Schupp, J.R. 2001. Performance of trees in the 1990 NC-140 apple cultivar/rootstock planting: Additional cultivars and rootstocks. Journal of the American Pomological Society 55: 178-184.

Jackson, J.E. 2003. Chapter 9: Flowers and fruits. In: Biology of Apples and Pears. New York, USA: Cambridge University Press. p. 268-308.

Jonkers, H. 1979. Biennial bearing in apple and pear: a literature survey. Scientia Horticulturae 11: 303-317.

Koepke, T. \& Dhingra, A. 2013. Rootstock scion somatogenetic interactions in perennial composite plants. Plant Cell Report 32: 1321-1337.

Kviklys, D., Kviklienè, N., Bielicki, P., Bite, A., Lepsis, J., Univer, T., Univer, N., Uselis, N. \& Lanauskas, J. 2013. Baltic fruit rootstock studies: evaluation of new apple (Malus domestica Borkh.) rootstocks. Zemdirbyste - Agriculture 100: 441-446.

Kviklys, D., Kviklienè, N., Bite, A., Lepsis, J., Univer, T., Univer, N., Uselis, N., Lanauskas, J. \& Buskienè, L. 2012. Baltic fruit rootstock studies: evaluation of 12 apple rootstocks in North-East Europe. Horticultural Science (Prague) 39: 1-7.

Kviklys, D., Liaudanskas, M., Janulis, V., Viškelis, P., Rubinskienė, M., Lanauskas, J. \& Uselis, N. 2014. Rootstock genotype determines phenol content in apple fruits. Plant, Soil and Environment 60: 234-240.

Kviklys, D. \& Robinson, T. 2010. Temperature before and after application of chemical thinners affects thinning response of 'Empire' apple trees. Acta Horticulturae 884: 525-530.

Lakso, A.N., Robinson, T.L. \& Greene, D.W. 2006. Integration of environment, physiology, and fruit abscission via carbon balance modeling - Implications for understanding growth regulator response. Acta Horticulturae 727: 321-326.

Monselise, S.P. \& Goldschmidt, E.E. 1982. Alternate bearing in fruit trees. Horticultural Reviews 4: 128-173.

Pellerin, B.P., Buszard, D., Iron, D., Embree, C.G., Marini, R.P., Nichols, D.S., Neilsen, G.H. \& Neilsen, D. 2011. A theory of blossom thinning to consider maximum annual flower bud numbers on biennial apple trees. HortScience 46: 40-42.

Piestrzeniewicz, C., Sadowski, A. \& Dziuban, R. 2009. Suitability of different dwarfing rootstocks for 'Rubin' apple trees grown in fertile soil. Journal of Fruit and Ornamental Plant Research 17: 53-62

Racsko, J. \& Miller, D.D. 2011. Effect of different growth inducing rootstocks on alternate bearing of 'Royal Gala' and 'Vista Bella' apples. Acta Horticulturae 903: 411-418.

Samuolienė, G., Čeidaitè, A., Sirtautas, R., Duchovskis, P. \& Kviklys, D. 2016. Crop load effect on phytohormones, sugars and biennial bearing in apple trees. Biologia Plantarum. DOI 10.1007/s10535-015-0581-3.

Schmidt, T., Elfving, D.C., McFerson, J.R. \& Whiting, M.D. 2009. Crop load overwhelms effects of gibberellic acid and ethephon on floral initiation in apple. HortScience 44: 1900-1906.

Schupp, J. 2011. Alternate Bearing in Fruit Crops. http://extension.psu.edu/plants/tree-fruit/news/2011/alternate-bearing-infruit-crops.

Wertheim, S.J. 1998. Rootstock guide: apple, pear, cherry, European plum. Fruit Research Station, Wilhelminadorp, The Netherlands. $144 \mathrm{p}$.

Wunsche, J.N. \& Ferguson, I.B. 2005. Crop load interactions in apple. Horticultural Reviews 31: 231-291.

Zurawicz, E., Bielicki, P., Czynczyk, A., Bartosiewicz, B., Buczek, M. \& Lewandowski, M. 2011. Breeding of apple rootstocks in Poland - the latest results. Acta Horticulturae 903: 143-150. 